\title{
UTILISATION OF WIND ENERGY POTENTIAL IN MONTENEGRO
}

\author{
Dejana Đurđevićl \\ Received: January 222017 | Accepted: July 18, 2017
}

\begin{abstract}
Research on the potential of wind energy in Montenegro was conducted by the Italian Ministry for the Environment, Land and Sea. Results are presented in the study - Assessing the potential of renewable energy sources (2007), where Montenegrin coast and area around Nikšić were recognized as potential sites for the construction of wind farms. If we consider only the areas that have a capacity factor of over $25 \%$, we conclude that Montenegro has wind energy potency of $100 \mathrm{MW}$. If we take into account the medium potential zone this value reaches $400 \mathrm{MW}$. By using the aforementioned energy resources to produce electricity 20-25\% of annual energy consumption in Montenegro could be provided. Up to now, studies of wind potential for two sites, Krnovo and Možura, have been submitted to Ministry of Economy. At the site Krnovo, construction of the wind farm began in May 2015, while the beginning of construction on the site Možura is still ahead. Montenegro also participates in the project of coastal wind farms, POWERED, which aims to explore the potential of wind in the Adriatic Sea for the construction of offshore wind farms.
\end{abstract}

Keywords: wind power, Krnovo, Mozura, POWERED, Montenegro

\section{INTRODUCTION}

In modern conditions of intense population growth and increasing consumption of fossil fuels, primarily oil, coal and natural gas, there are significant changes in the environment. By burning fossil fuels, gases with a greenhouse effect are released, which at the same time change the natural composition of the atmosphere. As a consequence, there is global warming and climate change (Rajović, Bulatović, 2013).Climate change, as the main ecological problem of the world community, was discussed at numerous international meetings and many declarations were made. Although there is no single solution to prevent climate change, it has been observed that greater use of alternative energy sources can significantly reduce carbon dioxide (CO2) levels and slow them down. The wind is recognized as one of the more attractive alternative sources of energy. Wind power has been used for navigation, pumping water, running mills, etc. since ancient

\footnotetext{
Pariske Komune 25, 21000 Novi Sad, contact: dejanadjurdjevic6@gmail.com
} 
times. With the development of electricity production, the use of wind for these purposes has also been developed. Wind energy was initially used by larger objects away from the central power grid and the farm, in order to join the massive construction of wind turbines of various sizes, located on land and water. The advantages of using wind power are the lack of gasses that pollute the environment, relatively inexpensive maintenance, and the fact that wind farms do not require additional energy sources for their work (Mikičić et al., 2006).

It is estimated that today at least 80 countries use wind energy for electricity generation. At the end of 2014, there were more than 268,000 wind generators that participated in the total electricity production with 3\% (GWEC, 2015). At the level of Europe, Denmark and Spain have the highest potential for wind energy use, where by 2025, production is expected to increase by $50 \%$. Europe is at the forefront of the construction of wind turbines on water, with $90 \%$ of the world's total wind turbines of this type (GWEC, 2011).Thanks to them, the release of $12.2 \mathrm{Mt} \mathrm{CO} 2$ into the air was avoided. So far, about 57,000 workers have been directly and indirectly engaged in their construction, and it is projected that this number will increase nearly four times by 2020. By using wind energy, employment at the EU level has increased by $30 \%$, and the income from production was $€ 23$ billion by 2010 . According to a survey conducted in 2013, 70\% of the EU's citizens believe that the future of electricity production is in alternative sources (http:// www.ewea.org/wind-energy-basics/facts/). According to Reyers et al. (2016), wind potentials are decreasing from northern and central Europe, to southern Europe and the Mediterranean, based on the CMIP5 model that they used for the period up to 2100 .

Analyzing the areas of higher altitudes in South-East Europe, besides solar energy, wind energy is characterized by significant potential as the energy of the future (Ban et al., 2013). Starting from the experience of EU member states, it is necessary to pay more attention to wind energy in the framework of national energy strategies (Mikičić et al., 2006). One of the priorities of Montenegro's energy policy, which is in line with the EU's energy policy, is sustainable energy development. It involves exploring the potential of renewable energy sources and increasing their share in total energy production. Pursuant to the Law on Energy and the Energy Development Strategy of Montenegro until 2030, the National Action Plan for the use of energy from renewable sources by 2020 was adopted. This plan defines the dynamics of the use of natural resources, as well as the planned use of technologies needed to meet the national target of $33 \%$ of the share of energy produced from renewable sources in the total final energy consumption.

The aim of the paper is to present the potentials of wind energy in Montenegro based on previous research by the relevant institutions, then present the energy revenue and utilization of wind energy at the plants currently installed, as well as to present an exhaustive analysis of the use of wind energy with countries in the region. 


\section{PREVIOUS EXPLORATION OF WIND POTENTIAL}

Research on the potential of wind energy use in Montenegro was carried out by the Ministry of Environmental Protection, Land and Sea of the Republic of Italy. The results were presented in the Assessment of Renewable Energy Potential Study, 2007. The analysis was first determined by theoretical mean wind speed and theoretical average wind potential at a reference height of $50 \mathrm{~m}$. On the basis of the relationship between the measured and simulated wind speeds, the real mean velocity and actual average wind potential in Montenegro at a height of $50 \mathrm{~m}$ were obtained (figure 1).

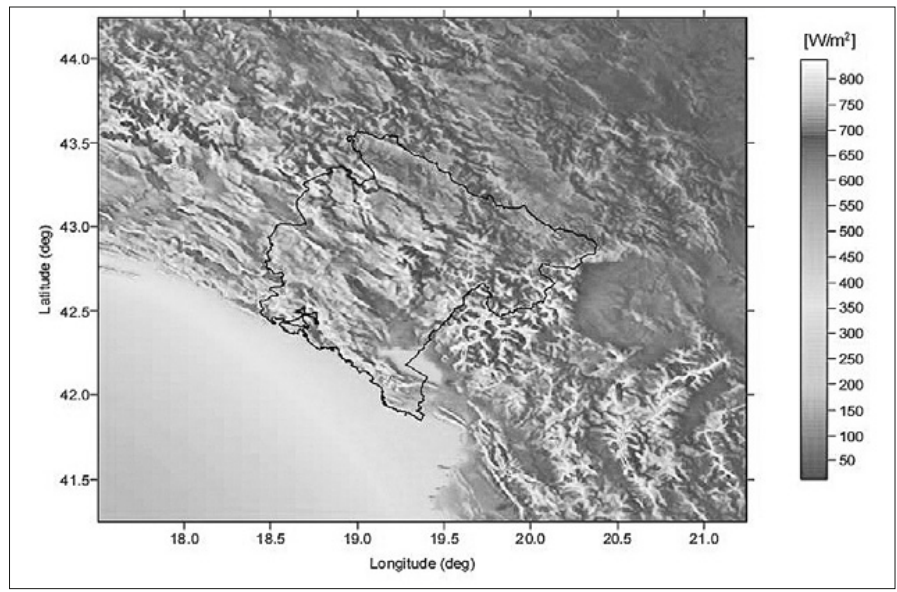

Figure 1: Actual wind potential in $\mathrm{W} / \mathrm{m} 2$ at $50 \mathrm{~m}$.

Source:CETMA, 2007.

A more detailed analysis was carried out, which included potential constraints, such as the relief of the site, its accessibility, the road network, proximity to protected areas, railroads, electricity networks and settlements. Based on this analysis, it has been concluded that Montenegro has significant potential for using wind energy in certain localities (figure 2). On most of the territory, wind speed is less than $5 \mathrm{~m} / \mathrm{s}$, which is typical for the territory of Central Europe. However, the speed increases further to the coast where it reaches a value of 7-8 m/s. In addition to the coast, the area around Nikšić is interesting, where the wind speed reaches values of 5.5-6.5m/s.Due to the developed network of transmission lines and roads, both areas are recognized as potential sites suitable for the construction of wind farms. The most vivid are mountain peaks where the real energy potential of the wind is over $400 \mathrm{~W} / \mathrm{m} 2$. However, according to all other characteristics, these sites are not suitable for exploitation. Of all national parks, only NP Lovćen can be suitable for the use of wind energy due to developed infrastructure and high wind speed (Ministry of Environmental Protection, Land and Sea of the Republic of Italy, 2007).

Due to the insufficiently developed transport infrastructure (except for several convenient locations), it would be most appropriate to choose smaller turbines, due to the easier transportation of their components. On the other hand, the installation of larger generators would produce a higher amount of electricity, which would depreciate the 


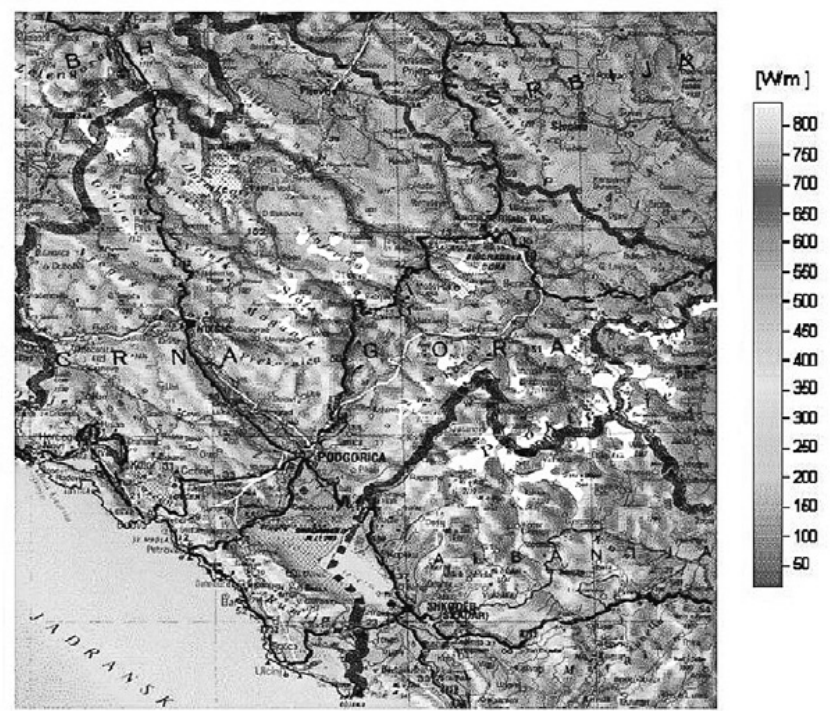

Figure 2: Actual wind potential in $\mathrm{W} / \mathrm{m} 2$ at $50 \mathrm{~m}$ with relevant restrictions Source: CETMA, 2007.

costs of improving the road infrastructure. Furthermore, a preliminary analysis of economic parameters in case of concrete construction of wind turbines in Montenegro was carried out. Various scenarios for different capacity factors $(20,25,30 \%)$ were analyzed corresponding to different mean wind speeds $(6.1 .6 .4$ and $7 \mathrm{~m} / \mathrm{s}$ ) for wind power generators with a nominal power of $850 \mathrm{~kW}$.

If we consider only areas with a capacity factor of over $25 \%$, we conclude that Montenegro has an energy potential of 100MW. Considering the mid-potential zones, this value reaches $400 \mathrm{MW}$. By using this energy potential for the production of electricity, 20-25\% of the annual energy consumption in Montenegro could be provided (CETMA, 2007).

\section{LOCATION OF WIND FARMS IN MONTENEGRO}

By the competent Ministry, several permits were issued for the measurement and research of wind potential in the territory of Montenegro. These companies are:Fersa Energias Renovables ${ }^{1}$ (license for the municipalities of Tivat, Bar, Ulcinj, Podgorica and Budva), Ivicom wind ${ }^{2}$ (Krnovo, Niksic), NTE ${ }^{3}$ (Rumija, Bar) and Dekar (Rumija, Bar).

1 Fersa Energias Renovables SA is one of the world's leading alternative energy companies, based in Barcelona, Spain. They own and are planning to build new wind farms in: India, Panama, Spain, China, France, Italy, Hungary, Montenegro, Poland, Estonia and Russia.

2 IVICOM Consulting GmbH is a consultancy, design and construction company in industrial plants. It was founded in 1991, based in Vienna.

3 Nord-Trøndelag Elektrisitetsverk AS (NTE) is a power generation company, based in Stykkhor, Norway. They own 28 hydropower plants and two wind farms, and are the leading company for the construction of wind generators along the coast of Norway. 
So far, the Ministry of Economy has submitted the reports of the analysis of the wind potential for two sites, Krnovo and Mozura. In addition, the Institute of Hydrometeorology and Seismology of Montenegro performs measurements of wind speed and direction at a height of $10 \mathrm{~m}$ at the automatic stations in Podgorica, Bar, Nikšić, Kolašin, Žabljak, Pljani, Herceg Novi and Ulcinj (www.oie-res.me).

Montenegro is also a participant in the cross-border IPA Adriatic project - POWERED. The aim of the project is to explore the potential of wind in the Adriatic Sea. It is realized by setting an anemometer network along the coast of the Adriatic Sea. The analysis of the obtained data will recognize the most favorable locations for the installation of wind turbines (www.powered-ipa.it).

\section{LOCATION KRNOVO}

Krnovo is a grassy plateau, surrounded by branches of the Vojnik, which steps down to the Nikšić polje (Radojičić, 2015). It is located in the territory of three municipalities: Niksic, Savnik and Pluzine. The planned project included 26 wind turbines (tabel 1), two overhead transmission lines (Krnovo-Brezna and Brezna-Kličevo), two new substations (Krnovo and Brezna) and buildings for the management of a wind farm. The construction began in May 2015, and the works were completed in October 2016. At the moment, the usage permit is being processed, after which the wind farm will be put into trial for two to three months (www.bankar.me). The wind power output will be $72 \mathrm{MW}$, and the planned annual output is 200 to $230 \mathrm{GWh}$. Wind farms are located at an altitude of about $1500 \mathrm{~m}$, while wind generators are at a relative height of $85 \mathrm{~m}$. Near the location of the wind farm there are houses and other facilities used as huts. The nearest village is Grozd $(2.3 \mathrm{~km})$, while the nearest town is Šavnik $(6.5 \mathrm{~km})$. Transmission line passes through several villages. Six houses are up to $200 \mathrm{~m}$ from the corridor, and the nearest is only $88 \mathrm{~m}$ away. The minimum allowed distance from the transmission line corridor is $60 \mathrm{~m}$.

Table 1. Results of wind speed measurement (m/s) for the period 09.09.2008-09.09.2009.

\begin{tabular}{|l|c|c|c|c|c|c|c|c|c|c|c|c|c|c|}
\hline Month & IX & X & XI & XII & I & II & III & IV & V & VI & VII & VIII & IX & Year \\
\hline Grozd & 6.22 & 5.29 & 5.58 & 8.11 & 6.66 & 9.09 & 8.66 & 5.01 & 5.61 & 5.24 & 5.34 & 6.07 & 7.74 & 6.24 \\
\hline Bukovik & 6.01 & 4.77 & 5.22 & 6.93 & 5.12 & 8.46 & 7.53 & 4.44 & 4.99 & 4.18 & 4.33 & 5.15 & 7.52 & 6.47 \\
\hline Konjsko & 4.29 & 3.96 & 4.51 & 6.89 & 4.68 & 6.75 & 6.55 & 3.89 & 4.48 & \multicolumn{5}{|c|}{ No data } \\
\hline
\end{tabular}

Source: http://www.oie-res.me/uploads/archive/lzvjestaj\%200\%20mjerenjima\%20-\%20Krnovo.pdf

The project, worth 120 million euros, is realized by Ivicom wind and Akuo Energy, Krnovo Green Energy is responsible for the construction, and the financiers are EBRD, German Development Bank and French Investment Company for Promoting Economic Cooperation Proparco (www.bankar.me).During construction, all standards related to environmental protection and working conditions have been met. The existing asphalt roads have been reconstructed and new roads have been built, which are expected to increase in the future the increase in the number of tourists and sports activities in this 


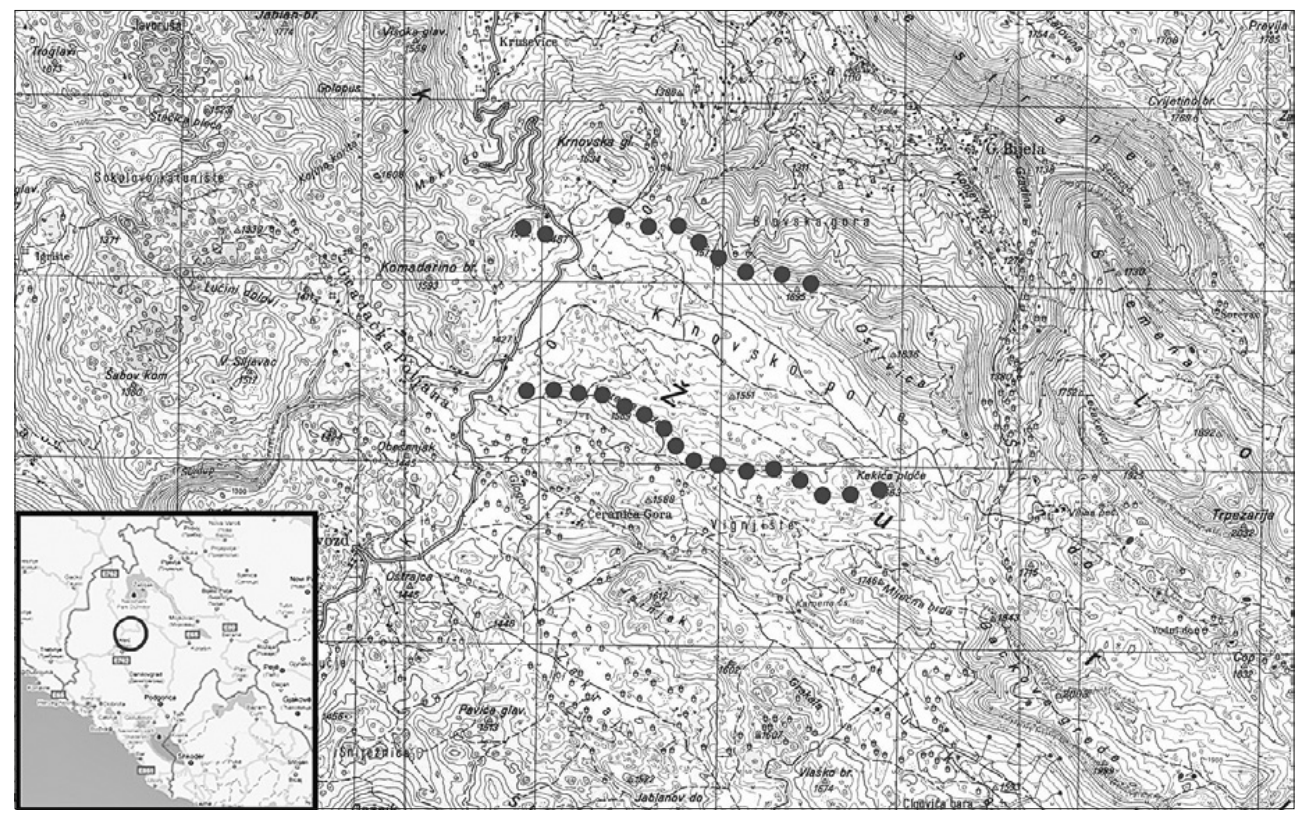

Figure 3: Position of the wind turbine inside the wind farm Krnovo

Source: KCE, 2015

region. The project employs a large number of workers, which contributes to the development of the local community.

Possible negative impacts expected during the phase of the operation are: damage to roads during construction works and transport of wind turbines, possible negative impact of wind turbines on birds and blind mice, and noise production during the operation of wind turbines (KGE, 2015).

Despite the listed negative effects, the project has great importance for the economy and sustainable development of Montenegro. The largest wind farm in the Region will significantly contribute to achieving Montenegro's energy goals by 2020 , which obliges $33 \%$ of total consumption to be from renewable energy sources.

\section{LOCATION MOŽURA}

Možura hill (622 m) is located on the coast, between Bar and Ulcinj (figure 4). Due to the rich biological diversity it has been declared as an area of special importance.

In the period from 2008-2009 on this site, observations were carried out for the needs of the construction of a wind farm by Fersa Energias Renovables. Wind speed was measured at altitudes of 40,60 and $68 \mathrm{~m}$. The obtained results were presented in the Report of the analysis of the wind potential measurement at the Možura locality, 2009 (table 2).

Montenegro has concluded a land lease agreement and the construction of a $46 \mathrm{MW}$ installed power plant on July 5, 2010. With this contract, state land has been leased to Fersa Energias Renovables for a period of 20 years. In 2015, the Ministry of Sustainable Development and Tourism issued a building permit for the construction of a wind farm, 


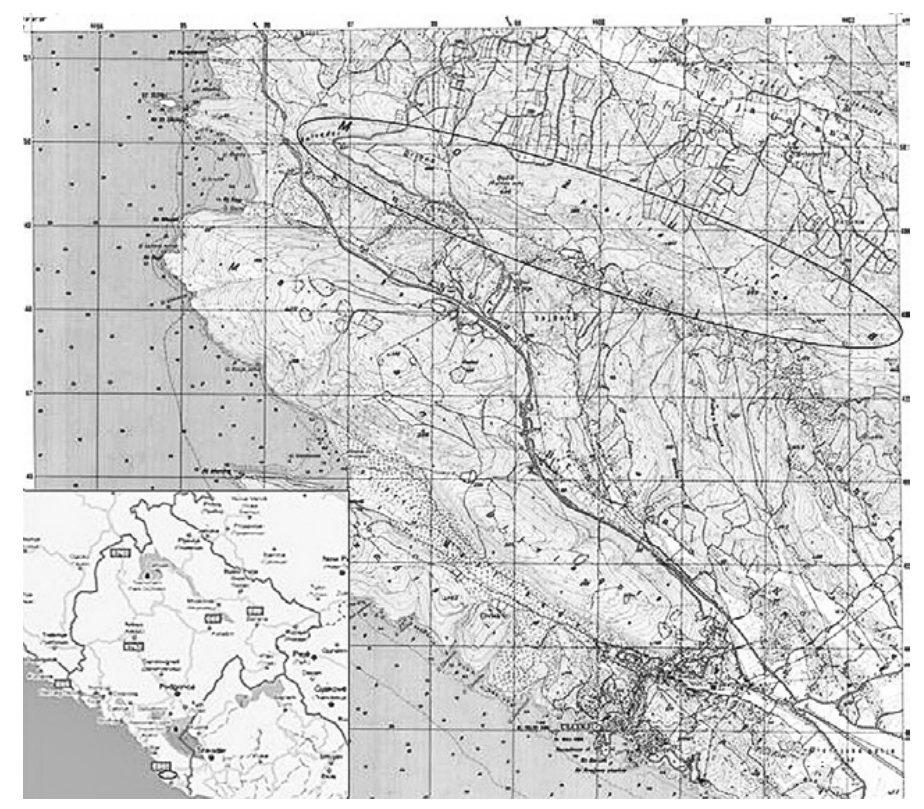

Figure 4. Location of Možura hill

Source: TK 1:25 000, Part of OTK, Ulcinj,VGI, 1980

however, the aforementioned company transferred the rights and obligations from the contract to Enemalta corporation, which showed great interest in investing in the energy sector in Montenegro. Currently, preparatory works are carried out on this site, which include the preparation of access road infrastructure, as well as the excavation of the terrain for future wind generators. The beginning of the main works is expected in the first months of 2017. The project envisages the installation of 23 wind power generators with $2 \mathrm{MW}$ of installed power (www.bankar.me).

Table 2. Measuring height and wind speed for the period 22.05.2008-22.05.2009.

\begin{tabular}{|c|c|c|c|c|}
\hline Hight & $\begin{array}{c}\text { Retrieved saved } \\
\text { data in \% }\end{array}$ & Captures & U* Max. m/s & U* Min. m/s \\
\hline $68.0 \mathrm{~m}$ & 100.0 & 52488 & 28.8 & 5.8 \\
\hline $60.0 \mathrm{~m}$ & 100.0 & 52488 & 28.6 & 5.7 \\
\hline $40.0 \mathrm{~m}$ & 100.0 & 52488 & 28.1 & 5.6 \\
\hline
\end{tabular}

Source:http://www.oie-res.me/uploads/archive/Izvjestaj\%200\%20mjerenjima\%20-\%20Mozura.pdf

\section{AREA OF THE ADRIATIC SEA}

Montenegro participates in the Coastal Wind Power Project, POWERED, which is financed through IPA Adriatica. The initiator and lead partner of the project is the province of Abruzzo in Italy. Other partners on this project are representatives of Montenegro, Croatia and Albania. The aim of the project is to explore wind potential in the 


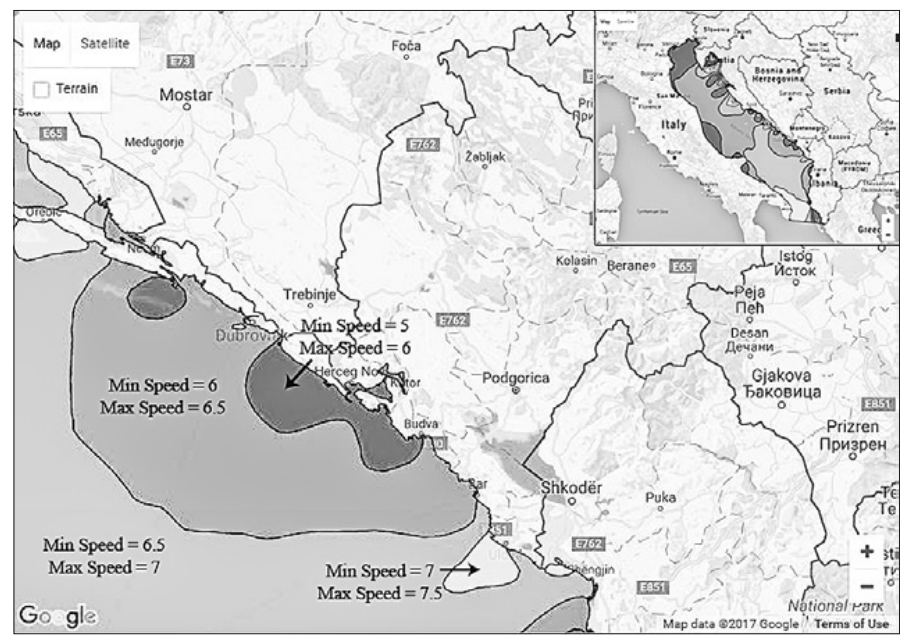

Figure 5: Map of the wind speed in the Adriatic Sea (territory of Montenegro) at a reference altitude of $90 \mathrm{~m}$ Source:http://www.powered-ipa.it/

Adriatic Sea to build possible offshore wind farms. For this purpose, the anemometers are located along the Adriatic Sea, on land and on the open sea, at a height of 40-60 m (www.oie-res.me).

On the territory of Montenegro an anemometric station is located in the vicinity of Ulcinj. It consists of eight meteorological towers, with five anemometers and four wind direction sensors, located at five different altitudes: 45, 40, 30, 20 and $10 \mathrm{~m}$ (http://www. powered-ipa.it/).

On the basis of the preliminary data obtained, a map of the wind velocity was made at a reference altitude of $90 \mathrm{~m}$ (figure 5).

\section{DISCUSSION AND CONCLUSION}

The production of electricity from renewable energy sources and the reduction of electricity production from plants using fossil fuels contribute to reducing the emission of harmful gases, primarily carbon dioxide $\left(\mathrm{CO}_{2}\right)$, and thus reducing the level of air pollution. Renewal and durability of wind power provides reliable and safe electricity supply, and the possibility of employment during the construction, operation and maintenance phase of the wind farm contributes to the development of the local community (KGE, 2015). At the same time, ecologically pure energy sources are introduced, i.e. Green energy (ESMAP, 2005; Mikičić et al., 2006; Rajović i Bulatović, 2013).

In addition to numerous positive features of wind use for electricity generation, there are also negative sides: initial capital investments are large, because they are built in isolated locations, the costs of transport are higher, and the approach is more difficult, which is especially characteristic for the territory of Montenegro. In addition to economic factors, it is also important to highlight the impact of wind farms on the environ- 
ment. It is reflected in disturbing landscape, producing high noise and potential hazards for birds and bets.

Like all other mechanical devices, wind generators produce a certain amount of noise during operation. Much of this noise is masked by the sound of the wind. In recent years, the design of the wind turbine has been perfected so that the sound production is reduced to a minimum. In addition, during construction, the selection of an adequate location and insulation material is important in order to minimize the negative impacts.

Because they require open terrain, most wind generators are very noticeable and have a great impact on the landscape's appearance. However, their visibility does not necessarily diminish the aesthetic value of the area. This is where Location Selection Strategies help. One of these Strategies proposes that a smaller number of wind turbines be installed in different locations within a larger zone, and that larger and more efficient models are used during construction.

One of the biggest and most significant negative effects of the construction of wind farms is their impact on the mortality of birds and bats. Although this effect is related to the construction of other buildings such as chimneys, lighthouses, high buildings, radio and TV receivers, it is also the concern of the wind industry. What has attracted the attention of the professional public is the fact that in some wind farms a higher mortality rate is recorded, while in some it is completely absent. Consequently, numerous studies have been carried out on the movement, crashes and relevant behavior of birds and bats and possible mitigation measures. Designers are obliged to collect relevant data through the monitoring of the current situation and the Assessment of the impact of the planned state. In order to mitigate the negative effects, location selection is also important.

The wind turbines do not produce any exhaust gases and the only danger for polluting the environment is small amounts of oil used for lubrication, maintenance of hydraulics and insulation. Therefore, the possibility of contamination of soil and groundwater is minimal (http://windeis.anl.gov/).

It is estimated that today at least 80 countries use wind energy for electricity generation. At the level of Europe, Denmark and Spain have the greatest potential for using wind power. The Republic of Serbia (1300MW), Bosnia and Herzegovina (900MW) and Croatia $(750 \mathrm{MW})$ have the highest wind potential in the area of Southeast Europe. Montenegro has a wind power of $400 \mathrm{MW}$, considering medium-potential zones. Also, the analysis of Ban and associates (Ban et al., 2013), the area of Montenegro has a moderate intensity of wind energy.

By using the mentioned energy potential in order to produce electricity, 20-25\% of annual energy consumption could be provided. So far, the Ministry of Economy has submitted the reports of the analysis of the wind potential for two sites, Krnovo and Mozura. At the site Krnovo, the construction of the wind farm started in May 2015, while the start of work at the Mozura locality is expected in March this year. Montenegro, along with Croatia, Albania and Italy, participates in the POWERED Coastal Power Project, financed through IPA Adriatica, which will enable the definition of new sites suitable for the construction of wind farms, especially along the coastal part of the Adriatic Sea. 


\section{REFERENCES}

Ban, M., Perković, L., Duić, N., Penedo, R. (2013). Estimating the spatial distribution of high altitude wind energy potential in Southeast Europe. Energy, 57, 24-29.

CETMA (2007). Procena potencijala obovljivih izvora energije u Crnoj Gori. Ministarstvo za zaštitu životne sredine, kopna i mora Republike Italije, 1-20.

ESMAP (2005). Renewable Energy Potential in Selected Countries. Volume I: North Africa, Central Europe, and the Former Soviet Union and Volume II: Latin America. The International Bank for Reconstruction and Development and The World Bank, Washington D.C, pp. 106.

GWEC (2011). Global Wind Report - Annual market update 2011.Global Wind Energy Council, Belgium, 1-68.

GWEC (2015). Global Wind Statistics 2014.Global Wind Energy Council, Belgium, 1-4. KGE (2015). Projekat vetroelektrana Krnovo. Krnovo Green Energy d.o.o., Podgorica, 1-7.

Mikičić, D., Radičević, B., Đurišić, Ž. (2006). Wind Energy Potential in the World and in Serbia and Montenegro, Facta Universitatis, 19, 47-61.

Radojičić, B. (2015). Crna Gora, Geografski enciklopedijski leksikon.Univerzitet Crna Gora, Filozofski fakultet Nikšić.

Rajović, G., Bulatović, J. (2013). Geographical view on energetic sources of climate northeastern Montenegro. International Letters of Natural Sciences, 3, 1-6.

Reyes, M., Moemken, J., Pinto J.G. (2016). Future changes of wind energy potentials over Europe in a large CMIP5 multi-model ensemble. International Journal of Climatology, 36, 783-796.

\section{WEB PAGES}

http://www.ewea.org/wind-energy-basics/facts/

http://www.greenchipstocks.com/

http://www.oie-res.me/

http://www.powered-ipa.it/

http://krnovo-ge.com/

http://www.bankar.me/

http://windeis.anl.gov/ 


\title{
КОРИШЋЕЊЕ ЕНЕРГЕТСКОГ ПОТЕНЦИЈАЛА ВЕТРА У ЦРНОЈ ГОРИ
}

\author{
Дејана Ђурђевић' \\ Примљено: 22.01.2017. | Прихваћено: 18.07.2017.
}

\begin{abstract}
АПСТРАКТ: Истраживање о потенцијалу коришћења енергије ветра у Црној Гори спровело је Министарство за заштиту животне средине, копна и мора Републике Италије. Резултати су презентовани у студији Процена потениијала обновљивих извора енергије (2007), где су као потенцијални локалитети за изградњу препозати Приморје, са средњом брзином ветра од 7-8m/s, и подручје око Никшића, где је средња брзина ветра5, 5-6,5m/s. Ако разматрамо само области које имају фактор капацитета преко 25\%, закључујемо да Црна Гора располаже енергетским потенцијом ветра од 100MW. Уколико се узму у обзир и зоне са средњим потенцијалом та вредност достиже 400MW. Коришћењем поменутог енергетског потенцијала у циљу производње електричне енергије могло би да се обезбеди 20-25\% годишње потрошње енергије у Црној Гори.Министарству економије су до сада достављени Извештаји анализе мерења потенцијала ветра за два локалитета, Крново и Можура. На локалитету Крново изградња ветропарка је почела у мају 2015. године, док се почетак радова на локалитету Можура очекујем у току 2017. године.Црна Гора је такође учесник Пројекта приобалних ветроелектрана, POWERED, чији је циљ истраживање потенцијала ветра на Јадранском мору.
\end{abstract}

Кључне речи: енергија ветра, Крново, Можура, POWERED, Црна Гора

\section{УВОД}

У савременим условима интензивног пораста броја становника и све веће потрошње фосилних горива, пре свега нафте, угља и природног гаса, долази до значајних промена у животној средини. Сагоревањем фосилних горива ослобађају се гасови са ефектом стаклене баште који, уједно, мењају природни састав атмосфере. Као последица тога, долази до глобалног загревања и промене климе (Рајовић, Булатовић, 2013). О климатским променама, као главном еколошком проблему светске заједнице, расправљало се на бројним међународним скуповима и донешене су многе декларације. Иако не постоји јединствено решење које би спре-

I Париске Комуне 25, 21 ооо Нови Сад, контакт: dejanadjurdjevic6@gmail.com 
чило климатске промене, уочено је да већа употреба алтернативних извора енергије може значајно да смањи ниво угљен-диоксида (CO2) и да их успори. Као један од атрактивнијих алтернативних извора енергије препознат је ветар. Снага ветра се од давнина користила за пловидбу, пумпање воде, покретање млинова, итд. Са развојем производње електричне енергије, развијала се и примена ветра у те сврхе. Енергију ветра су у почетку користили већи објекти који су удаљени од централне електричне мреже и фарме, да би се потом, приступило масовнијој изградњи ветрогенератора различитих величина, смештених на копну и води. Предности коришћења енергије ветра су непостојање гасова који загађују животну средину, релативно јефтино одржавање и чињеница да ветроелектране за свој рад не захтевају додатне изворе енергије (Микичић и др., 2006).

Процењено је да данас најмање 80 држава света користе енергију ветра за производњу електричне енергије. На крају 2014. године радило је више од 268000 ветрогенератора који су учествовали у укупној производњи електричне енергије ca 3\%(GWEC, 2015).

На нивоу Европе, највећи потенцијал за коришћење енергије ветра имају Данска и Шпанија, где се до 2025. предвиђа пораст производње за 50\%. Европа се налази на првом месту у изградњи ветрогенератора на води, са 90\% од укупних светских ветрогенератора овог типа(GWEC, 2011). Захваљујући њима, избегнуто је испуштање 12,2 Mt CO2 у ваздух. До сада је на њиховој изградњи директно и индиректно ангажовано око 57000 радника, а предвиђено је да ће се тај број до 2020. повећати скоро четири пута. Коришћењем енергије ветра запосленост на нивоу ЕУ је порасла за 30\%, а приход од производње је до 2010. износио 23 милијарде €. Према анкети која је спроведена 2013. године 70\% становника ЕУ сматра да је будућност производње електричне енергије у алтернативним изворима (http://www. ewea.org/wind-energy-basics/facts/). Према истраживањима Рејерса и сарадника (Reyers et al., 2016), потенцијали ветра се смањују од северне и централне Европе, према јужној Европи и Медитерану, базирано на CMIP5 моделу који су користили за период до 2100. године.

Анализирајући просторе виших надморских висина у Југоисточној Европи, поред соларне енергије, енергије ветра карактерише значајним потенцијалом као енергије будућности (Бан и др., 2013). Полазећи од искуства земаља чланица ЕУ, неопходно је да се енергији ветра посвети више пажње у оквиру националних Стратегија енергетике (Микичић и др., 2006). Један од приротета енергетске политике Црне Горе, која је у складу саенергетском политиком ЕУ, је и одрживи енергетски развој. Он подразумева истраживање потенцијала обновљивих извора енергије и повећање њиховог удела у укупној енергетској производњи. На основу Закона о енергетици и Стратегије развоја енергетике Црне Горе до 2030. године, донет је Национални акциони план коришћења енергије из обновљивих извора до 2020. године.Овим планом се дефинише динамика коришћења природних потенцијала, као и планирано коришћење технологијапотребних за задовољење националног циља од 33\% удела енергије произведе из обновљивих извора у укупној финалној потрошњи енергије. Поред Националног акционог плана, важан стра- 
тешки документ је и Програм развоја и коришћења обновљивих извора енергије који се дефинише за период од десет година (http://www.oie-res.me/).

Циљ рада је да прикаже потенцијале енергије ветра у Црној Гори на основу досадашњих истраживања релевантних институција, затим презентује енергетски приход и искоришћеност енергије ветра на тренутно инсталисаним постројењима, као и да се представи уропредна анализа коришћења енергије ветра са земљама у окружењу.

\section{ДОСАДАШЊА ИСТРАЖИВАЊА ПОТЕНЦИЈАЛА ЕНЕРГИЈЕ ВЕТРА}

Истраживање о потенцијалу коришћења енергије ветра у Црној Гори спровело је Министарство за заштиту животне средине, копна и мора Републике Италије. Резултати су презентовани у студији Процјена потенцијала обновљивих извора енергије, 2007. Приликом анализе је најпре одређена теоријски средња брзина ветра и теоријски просечни потенцијал ветра на референтној висини од $50 \mathrm{~m}$. На основу односа између измерених и симулираних брзина ветра добијена је стварна средња брзина и стварни просечни потенцијал ветра у Црној Гори на висини од $50 \mathrm{~m}$ (прилог 1).

Даље је извршена детаљнија анализа која је обухватала потенцијална ограничења, као што су рељеф локалитета, његова приступачност, путна мрежа, близина заштићених предела, железничких пруга, електричне мреже и насељених места. На основу ове анализе дошло се до закључка да Црна Гора располаже значајним потенцијалом за коришћење енергије ветра на појединим локалитетима (прилог 2). На већем делу територије брзина ветра је мања од $5 \mathrm{~m} / \mathrm{s}$, што је карактеристично за територију Централне Европе. Ипак, брзина се повећава идући ка приморју где достиже вредности од 7-8m/s. Поред приморја, интересантна је и област око Никшића где брзина ветра достиже вредности од 5,5-6,5m/s. Оба под-

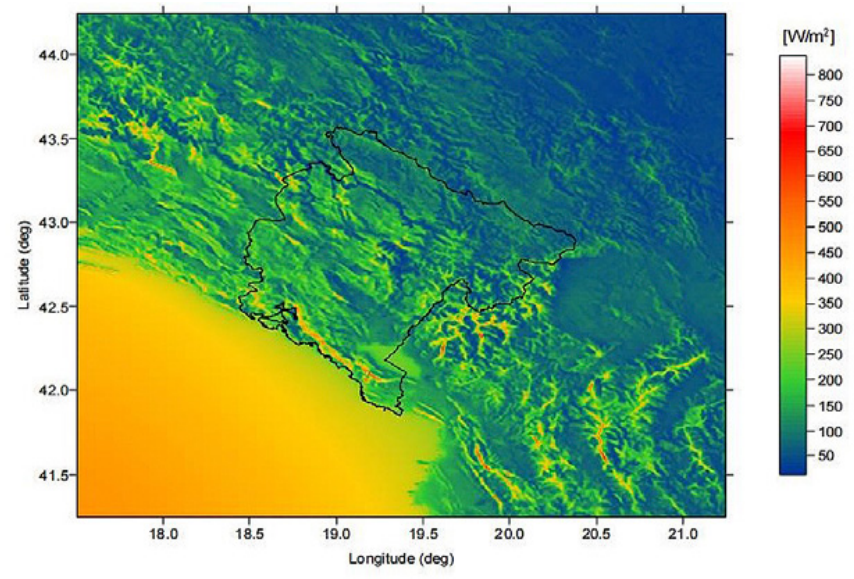

Прилог 1. Стварни енергетски потенцијал ветра у W/m2 на 50m н.в. 
ручја су због развијене мреже далековода и путева препозната као потенцијални локалитети погодни за изградњу ветропаркова. Најветровитији су планински врхови где стварни енергетски потенцијал ветра износи преко $400 \mathrm{~W} / \mathrm{m} 2$. Међутим, по свим другим карактерситикама, ови локалитети нису погодни за искориштавање. Од свих националних паркова, једино НП Ловћен може да буде погодан за коришћење енергије ветра због развијене инфраструктуре и велике брзине ветра (Министарство за заштиту животну средину, копно и море Републике Италије, 2007).

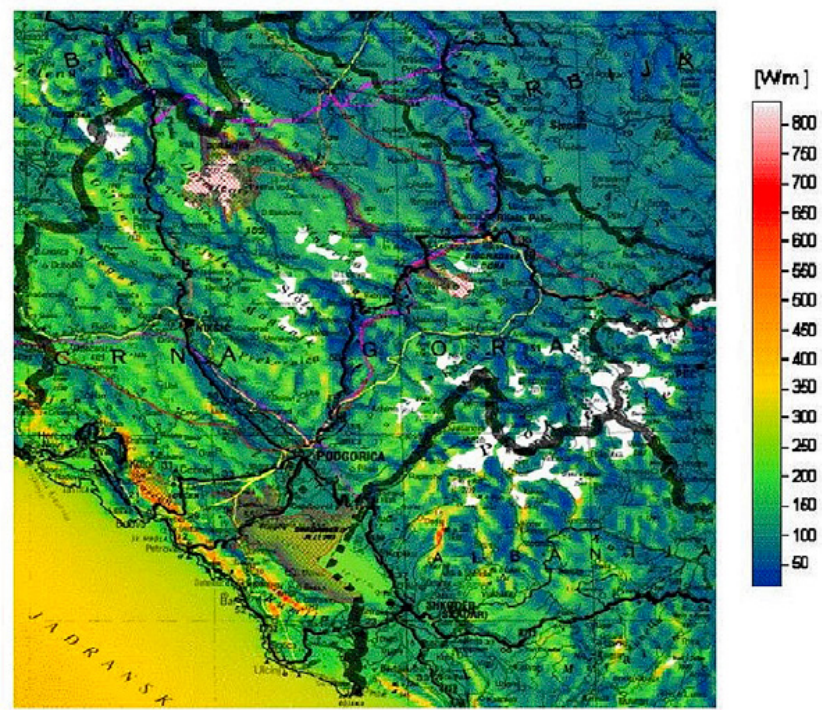

Прилог 2. Стварни енергетски потенцијал ветра у W/m2 на 50m н.в. уз релевантна ограничења Извор: СЕTМА, 2007.

Због недовољно развијене саобраћајне инфраструктуре (изузев неколико погодних локација) било би најпогодније изабрати мање турбине, због лакшег превоза њихових саставних делова. Са друге стране, инсталирање већих генератора би произвело и већу количину електричне енергије,што би амортизовало трошкове усавршавања путне инфраструктуре. Даље је извршена прелиминарна анализа економских параметара у случају конкретне изградње ветрогенератора у Црној Гори. Анализирани су разни сценаријуми за различите факторе капацитета $(20,25,30 \%)$ који одговарају различитим средњим брзинама ветра $(6,1,6,4$ и $7 \mathrm{~m} / \mathrm{s})$ за ветрогенераторе номиналне снаге $850 \mathrm{~kW}$.

Ако разматрамо само области које имају фактор капацитета преко $25 \%$, закључујемо да Црна Гора располаже енергетским потенцијом ветра од 100MW. Уколико се узму у обзир и зоне са средњим потенцијалом та вредност достиже 400MW. Коришћењем поменутог енергетског потенцијала у циљу производње електричне енергије могло би да се обезбеди 20-25\% годишње потрошње енергије у Црној Гори(CETMA, 2007). 


\section{ЛОКАЦИЈЕ ВЕТРОПАРКОВА У ЦРНОЈ ГОРИ}

Од стране надлежног Министарства, издато је неколико дозвола за мерење и истраживање потецијала ветра на теритрији Црне Горе. У питању су компаније:Fersa Energias Renovables ${ }^{1}$ (дозвола за подручје општина Тиват, Бар, Улцињ, Подгорица и Будва), Ivicom wind ${ }^{2}$ (Горње и Доње Крново, Никшић), NTE $^{3}$ (Румија, Бар) и Dekar (Румија, Бар).

Министарству економије су до сада достављени Извештаји анализе мерења потенцијала ветра за два локалитета, Крново и Можура. Поред тога, Завод за хидрометеорологију и сеизмологију Црне Горе врши мерења брзине и правца ветра на висини од $10 \mathrm{~m}$, на аутоматским станицама у Подгорици, Бару, Никшићу, Колашину, Жабљаку, Пљивљима, Херцег Новом и Улцињу (www.oie-res.me).

Црна Гора је и учесник прекограничног IPA Adriatic пројекта - POWERED. Циљ пројекта је истраживање потенцијала ветра на Јадранском мору. Реализује се постављањем мреже анемометара дуж обале Јадранског мора. Анализом добијених података препознаће се најповољније локације за постављање ветрогенератоpa (www.powered-ipa.it).

\section{ЛОКАЛИТЕТ КРНОВО}

Крново је травната висораван, окружена огранцима Војника која се степеничасто спушта према Никшићком пољу (Радојичић, 2015). Налази се на територији три општине: Никшић, Шавник и Плужине. Планираним пројектом изграђено је 26 ветрогенератора (прилог 3), два надземна далековода (Крново-Брезна и Брезна-Кличево), две нове трафостанице (Крново и Брезна) и зграде за управљање ветроелектраном.Изградња је започета у мају 2015., а радови су завршени у октобру 2016. године. Тренутно је у поступку добијање употребне дозволе, након чега ће се ветропарк ставити у пробни рад два до три месеца (www.bankar.me).Излазна снага ветроелектране ће бити 72MW, а планирана годишња производња 200 до $230 \mathrm{GWh}$. Ветроелектране су постављене на надморској висини од око $1500 \mathrm{~m}$, док се ветрогенератори налазе на релативној висини од $85 \mathrm{~m}$. У близини локације ветроелектране постоје куће и други објектикоји се користе као катуни. Најближе село је Грозд $(2,3 \mathrm{~km})$, док је најближи град Шавник $(6,5 \mathrm{~km})$. Далековод прелази преко неколико села. Шест кућа је удаљено до 200m од коридора, а најближа је удаљена само $88 \mathrm{~m}$. Минимална дозвољена удаљеност од коридора далековода је $60 \mathrm{~m}$.

1 Fersa Energias Renovables SA је једна од водећих светских компанија које се бави алтернативним изворима енергије, са седиштем у Барселони, Шпанија. Поседују и планирају изградњу нових ветропаркова у : Индији, Панами, Шпанији, Кини, Француској, Италији, Мађарској, Црној Гори, Пољској, Естонији и Русији.

2 IVICOM Consulting GmbH је компанија која се бави саветовањем, пројектовањем и вођењем градње у индустријским постројењима. Основана је 1991., са седиштем у Бечу.

3 Nord-Trøndelag Elektrisitetsverk AS (NTE) је компанија за производњу електричне енергије, са седиштем у Стајнкјору, Норвешка. У њиховом власништву је 28 хидроцентрала и два ветропарка, а водећа су компанија за изградњу ветрогенератора дуж обале Норвешке. 
Табела 1. Резултати мерења брзине ветра (m/s) за период од 09.09.2008 до 09.09.2009.

\begin{tabular}{|l|c|c|c|c|c|c|c|c|c|c|c|c|c|c|}
\hline Месец & IX & X & XI & XII & I & II & III & IV & V & VI & VII & VIII & IX & год. \\
\hline Гвозд & 6.22 & 5.29 & 5.58 & 8.11 & 6.66 & 9.09 & 8.66 & 5.01 & 5.61 & 5.24 & 5.34 & 6.07 & 7.74 & 6.24 \\
\hline Буковик & 6.01 & 4.77 & 5.22 & 6.93 & 5.12 & 8.46 & 7.53 & 4.44 & 4.99 & 4.18 & 4.33 & 5.15 & 7.52 & 6.47 \\
\hline Коњско & 4.29 & 3.96 & 4.51 & 6.89 & 4.68 & 6.75 & 6.55 & 3.89 & 4.48 & \multicolumn{7}{|c|}{ прекид мерења } & 5.66 \\
\hline
\end{tabular}

Извор: http://www.oie-res.me/uploads/archive/Izvjestaj\%200\%20mjerenjima\%20-\%20Krnovo.pdf

Пројекат, чија је вредност 120 милиона евра, реализују фирма Ivicom wind и Akuo energy, застуник за изградњу је Krnovo Green Energy, а финансијери су EBRD, Немачка банка за развој и француска Инвестициона компанија за промовисање економске сарадње Proparco (www.bankar.me). Приликом изградње испуњени су сви стандарди у вези са заштитом животне средине и радним условима. Реконструисани су постојећи асфалтни путеви и изграђени су нови путеви за које се очекује да у будућности утичу на повећање броја туриста и спортских активности у овом крају. На пројекту је запослен већи број радника, што доприноси и развоју локалне заједнице.

Могући негативни утицаји који се очекују током фазе рада су:оштећеност путева приликом грађевинских радова и превоза ветрогенератора,могући негативни утицајветрогенератора на птице и слепе мишеве и производња буке приликом рада ветрогенератора (KGE, 2015).

И поред набројаних негативних утицаја, пројекат има велики значај за економију и одрживи развој Црне Горе. Највећи ветропарк у Региону значајно ће допри-

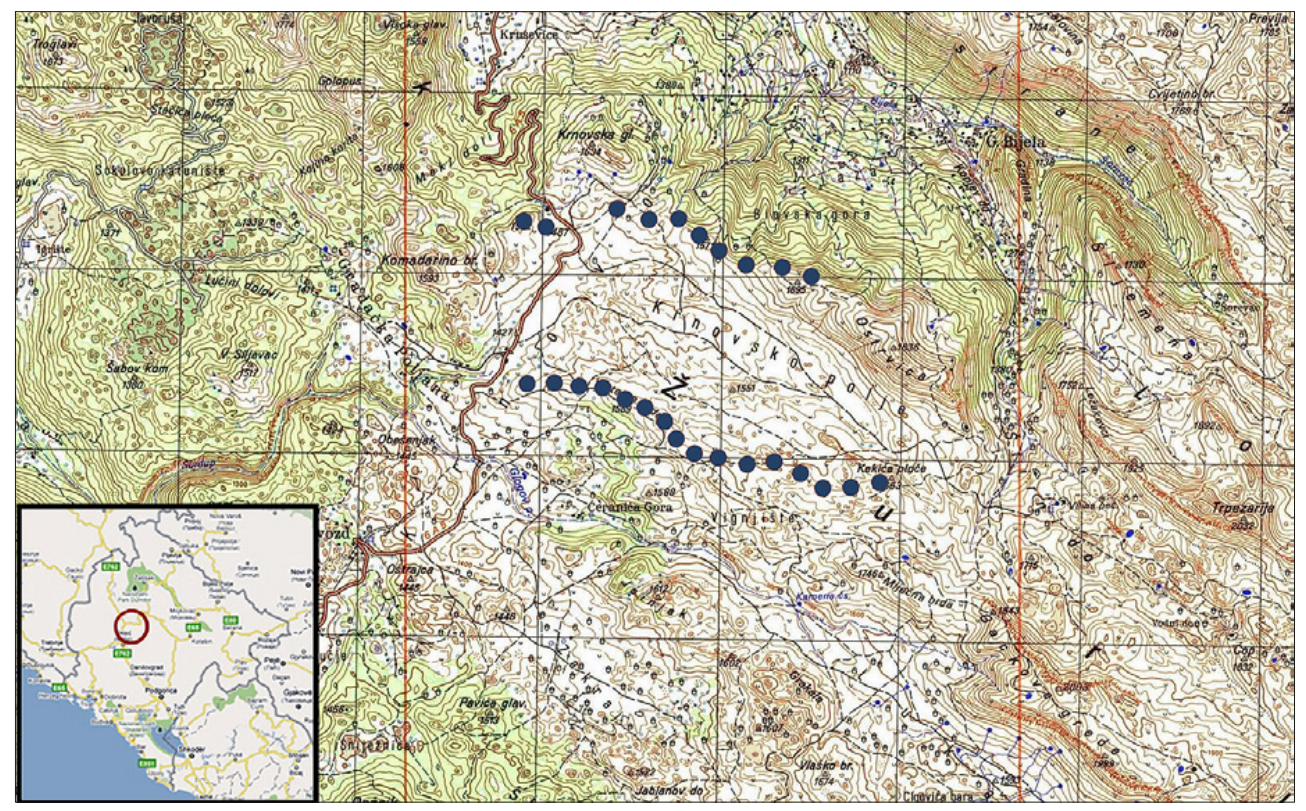

Прилог 3. Положај ветрогенератора унутар ветропарка Крново Извор: КСE, 2015 
нети остварењу енергетских циљева Црне Горе до 2020. године, који обавезују да 33\% укупне потрошње буде из обновљивих извора енергије.

\section{ЛОКАЛИТЕТ МОЖУРА}

Брдо Можура(622m) се налази на Приморју, између Бара и Улциња (прилог 4). Због богате биолошке разноврсности прогласено је Подручјем од посебног значаја.

У периоду од 2008-2009. године на овом локалитету су вршена осматрања за потребе изградње ветроелектране од стране компаније Fersa Energias Renovables. Измерена је брзина ветра на висинама од 40,60 и $68 \mathrm{~m}$. Добијени резултати су представљени у Извештају анализе мерења потенцијала ветра на локалитету Можура,2009 (табела 2).

Црна Гора је закључила Уговор о закупу земљишта и изградњи вероелектране инсталисане снаге 46MW 5.jула 2010. Овим уговором је државно земљиште дато у закуп компанији Fersa Energias Renovables на период од 20 година. Министарство одрживог развоја и туризма је 2015. године издало грађевинску дозволу за изградњу ветроелектране, међутим поменута компанија је пренела права и обавезе из Уговора на компанију Enemalta corporation која је показала велико интересовање за инвестирање у енергетски сектор у Црној Гори. Тренутно се на овој локацији изводе припремни радови који обухватају припрему приступне путне инфраструктуре, као и ископавање терена за будуће ветрогенераторе. Почетак главних радова очекује се у првим месецима 2017. године. Пројектом је предвиђе-

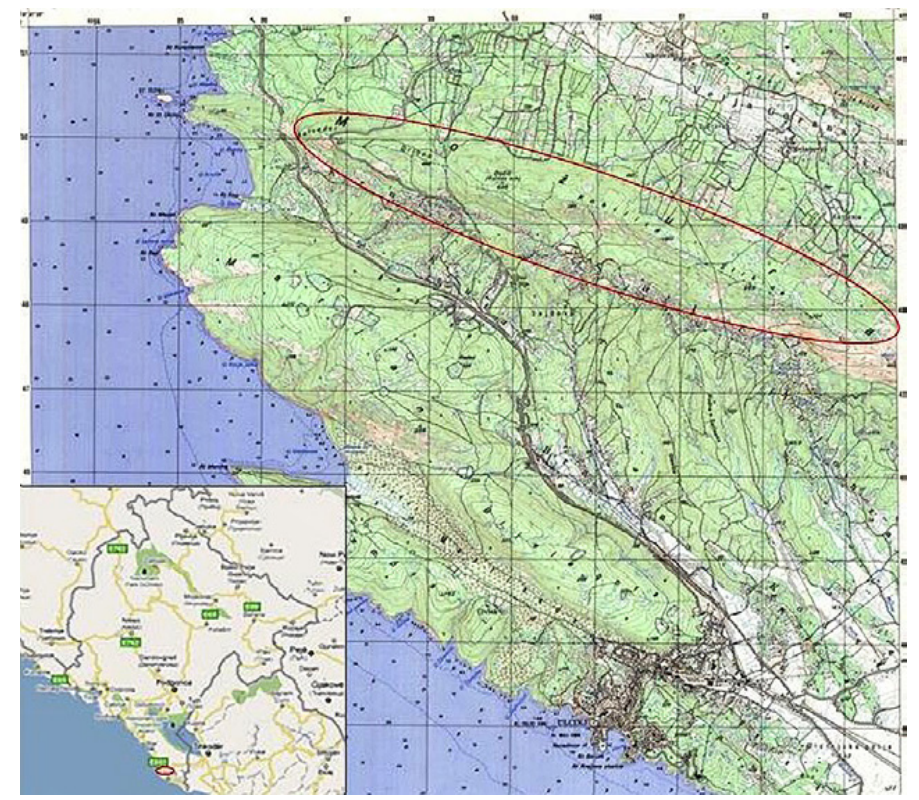

Прилог 4. Географски положај брда Можура Извор: ТК 1:25 000, Исечак из ОТК, лист Улцињ,ВГИ, 1980 
но постављање 23 ветрогенератора са по 2MW инсталисане снаге (www.bankar. me).

Табела 2. Висина мерења и брзина ветра за период 22.05.2008-22.05.2009. године

\begin{tabular}{|c|c|c|c|c|}
\hline Висина & $\begin{array}{c}\text { Добијени спасени } \\
\text { подаци у \% }\end{array}$ & Снимања & U* макс. m/s & U* мин. m/s \\
\hline $68.0 \mathrm{~m}$ & 100.0 & 52488 & 28.8 & 5.8 \\
\hline $60.0 \mathrm{~m}$ & 100.0 & 52488 & 28.6 & 5.7 \\
\hline $40.0 \mathrm{~m}$ & 100.0 & 52488 & 28.1 & 5.6 \\
\hline
\end{tabular}

Извор:http://www.oie-res.me/uploads/archive/lzvjestaj\%200\%20mjerenjima\%20-\%20Mozura.pdf

\section{ПОДРУЧЈЕ ЈАДРАНСКОГ МОРА}

Црна Гора је учесник Пројекта приобалних ветроелектрана, POWERED, који је финансиран путем IPA Adriatica. Иницијатор и водећи партнер пројекта је покрајина Абруцо у Италији. Остали партнери на овом пројекту су представници Црне Горе, Хрватске и Албаније. Циљ пројекта је истраживање потенцијала ветра на Јадранском мору ради изградње могућих приобалних ветроелектрана. У ту сврху су дуж Јадранског мора, на копну и на пучини, на висини од 40-60m, постављени анемометри (www.oie-res.me).

На територији Црне Горе постављена је једна анемометарска станица која се налази у околини Улциња. Састоји се од осам метеоролошких торњева, са по пет анемометара и четири сензора за правац ветра, који су постављени на пет различитих надморских висина: 45, 40, 30, 20 и 10m (http://www.powered-ipa.it/).

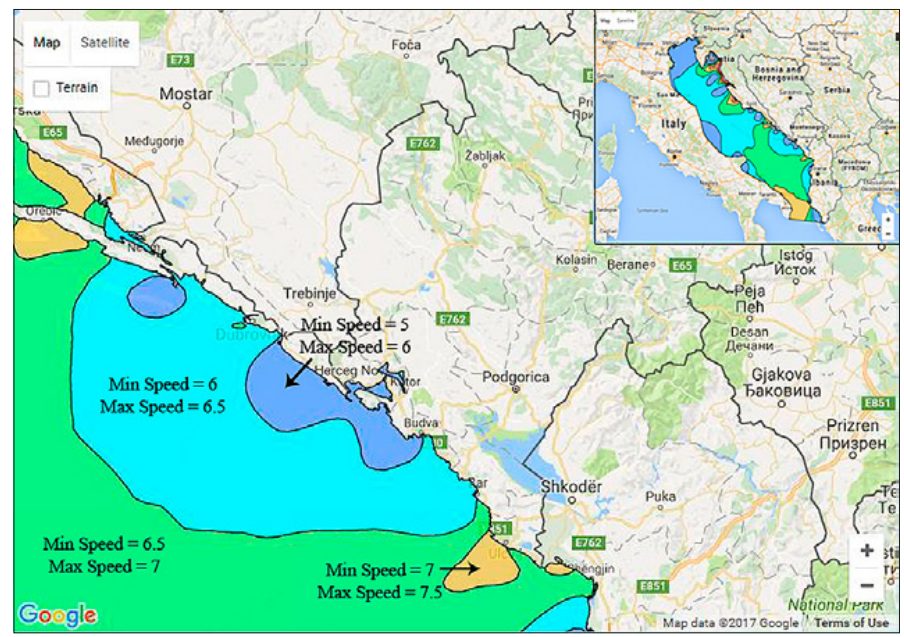

Прилог 5. Карта брзине ветра на Јадранском мору (територија Црне Горе) на референтној надморској висини од 90m 
На основу добијених прелиминарних података урађена је карта брзине ветра на референтној надморској висини од 90m (прилог 5).

\section{ДИСКУСИЈА И ЗАКЉУЧНА РАЗМАТРАЬА}

Производња електричне енергије из обновљивих извора енергије и смањење производње електричне енергије из постројења која користе фосилна горива доприноси смањењу емисије штетних гасова, пре свега угљен-диоксида $\left(\mathrm{CO}_{2}\right)$, а самим тим и смањује ниво загађености ваздуха. Обновљивост и трајност енергије ветра обезбеђује поуздано и сигурно снабдевање електричном енергијом, а могућност запошљавања у току фазе изградње, рада и одржавања ветропаркова доприноси развоју локалне заједнице (KGE, 2015). Истовремено, уводе се еколошки чисти извори енергије, тј. зелена енергија (ESMAP, 2005; Микичић и др., 2006; Рајовић и Булатовић, 2013).

Поред бројних позитивних одлика коришћења ветра за производњу електричне енергије, постоје и негативне стране: почетна улагања капитала су велика, због тога што се граде на изолованим локацијама трошкови транспорта су већи, а приступ је тежи, што је нарочито карактеристично за простор Црне Горе. Поред економских фактора, значајно је истаћи и утицај ветроелектрана на животну средину. Он се огледа у нарушавању пејзажа, производњи велике буке и потенцијалној опасности за птице и слепе мишеве.

Као и сви остали механички уређаји, и ветрогенератори производе буку одређене јачине приликом рада. Већи део ове буке је маскиран самим звуком ветра. Последњих година, дизајн ветрогенератора је усавршен тако да је производња звука сведена на минимум. Поред тога, приликом изградње, важан је и одабир адекватне локације и изолационог материјала како би се негативни утицаји свели на минимум.

Због тога што захтевају отворен терен, већина ветрогенератора је веома уочљива и има велики утицај на изглед пејзажа. Међутим, њихова видљивост не мора нужно да умањи естетску вредност предела. У томе помажу Стратегије за избор локације. Једна од тих Стратегија предлаже да се постави мањи број ветрогенератора на различитим местима унутар веће зоне, као и да се приликом изградње користе већи и много ефикаснији модели.

Један од највећих и најзначајнијих негативних ефеката изградње ветроелектрана је њихов утицај на смртност птица и слепих мишева. Иако је овај ефекат везан и за изградњу других грађевина као што су димњаци, светионици, високе зграде, радио и ТВ пријемници, он је и брига индустрије ветра. Оно што је привукло пажњу стручне јавности је чињеница да је у неким ветропарковима забележена већа стопа смртности, док је у неким она потпуно одсутна. 3бог тога су спроведена бројна истраживања о кретању, сударима и релевантном понашању птица и слепих мишева и могућим ублажавајућим мерама. Пројектанти су дужни да прикупе релевантне податке кроз мониторинг постојећег стања и Проце- 
ну утицаја планираног стања. За ублажавање негативних ефеката важан је и избор локације.

Ветрогенератори не производе никакве издувне гасове и једину опасност по загађење животне средине представљају мале количине уља које се користи за подмазивање, одржавање хидраулике и изолације. Због тога је могућност загађивања земљишта и подземних вода минимална(http://windeis.anl.gov/).

Процењено је да данас најмање 80 држава света користе енергију ветра за производњу електричне енергије. На нивоу Европе, највећи потенцијал за коришћење енергије ветра имају Данска и Шпанија. На подручју Југоисточне Европе највећи потенцијал ветра има Република Србија (1300MW), затим Босна и Хергецовина (900MW) и Хрватска (750MW). Црна Гора располаже енергетским потенцијом ветра од 400MW, уколико се узму у обзир и зоне са средњим потенцијалом. Такође, анализе Бана и сарадника (Ban et al., 2013), простор Црне Горе располаже са умереним интензитетом енергије ветра.

Коришћењем поменутог енергетског потенцијала у циљу производње електричне енергије могло би да се обезбеди 20-25\% годишње потрошње енергије. Министарству економије су до сада достављени Извештаји анализе мерења потенцијала ветра за два локалитета, Крново и Можура. На локалитету Крново, изградња ветропарка је почела у мају 2015. године, док се почетак радова на локалитету Можура очекује у марту,ове године. Црна Гора је, заједно са Хрватском, Албанијом и Италијом, учесник Пројекта приобалних ветроелектрана, POWERED, који је финансиран путем IPA Adriatica, што ће омогућити дефинисање нових локалитета погодних за изградњу ветропаркова, нарочито уз приобални део Јадранског мора.

\section{ЛИТЕРАТУРА}

Ban, M., Perković, L., Duić, N., Penedo, R. (2013). Estimating the spatial distribution of high altitude wind energy potential in Southeast Europe. Energy, 57, 24-29.

CETMA (2007). Процена потенцијала обновљивих извора енергије у Црној Гори. Министарство за заштиту животне средине, копна и мора Републике Италије, $1-20$.

ESMAP (2005). Renewable Energy Potential in Selected Countries. Volume I: North Africa, Central Europe, and the Former Soviet Union and Volume II: Latin America. The International Bank for Reconstruction and Development and The World Bank, Washington D.C, pp. 106.

GWEC (2011). Global Wind Report - Annual market update 2011.Global Wind Energy Council, Belgium, 1-68.

GWEC (2015). Global Wind Statistics 2014.Global Wind Energy Council, Belgium, 1-4. KGE (2015). Пројекат ветроелектрана Крново. Krnovo Green Energy d.o.o., Подгорица, 1-7.

Mikičić, D., Radičević, B., Đurišić, Ž. (2006). Wind Energy Potential in the World and in Serbia and Montenegro, Facta Universitatis, 19, 47-61. 
Радојичић, Б. (2015). Црна Гора, Географски енциклопедијски лексикон.Универзитет Црна Гора, Филозофски факултет Никшић.

Rajović, G., Bulatović, J. (2013). Geographical view on energetic sources of climate northeastern Montenegro. International Letters of Natural Sciences, 3, 1-6.

Reyes, M., Moemken, J., Pinto J.G. (2016). Future changes of wind energy potentials over Europe in a large CMIP5 multi-model ensemble. International Journal of Climatology, 36, 783-796.

\section{ИНТЕРНЕТ СТРАНИЦЕ:}

http://www.ewea.org/wind-energy-basics/facts/

http://www.greenchipstocks.com/

http://www.oie-res.me/

http://www.powered-ipa.it/

http://krnovo-ge.com/

http://www.bankar.me/

http://windeis.anl.gov/ 